НАУКОВИЙ ВІСНИК

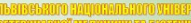

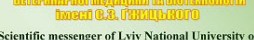

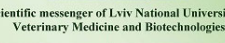

(20)

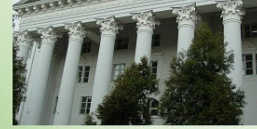

SPRirs",

Том 21 № 91

2019
Науковий вісник Дьвівського національного університету ветеринарної медицини та біотехнологій імені С.3. Гжицького. Серія: Сільськогосподарські науки

Scientific Messenger of Lviv National University of Veterinary Medicine and Biotechnologies. Series: Agricultural sciences

UDC 636.088:636.5

\title{
Features of providing broiler chickens with exchange energy and protein as important indicators of productivity and quality of the obtained products
}

\author{
L.M. Fijalovych, Ya.I. Kyryliv, G.A. Paskevych \\ Stepan Gzhytskyj National University of Veterinary Medicine and Biotechnologies Lviv, Ukraine
}

Article info

Received 10.09.2019

Received in revised form 08.10 .2019

Accepted 09.10.2019

Stepan Gzhytskyi National University of Veterinary Medicine and Biotechnologies Lviv,

Pekarska Str., 50, Lviv,

79010, Ukraine.

Tel.:+38-096-355-38-58

E-mail: lesya_fiyalovych@ukr.net
Fijalovych, L.M., Kyryliv, Ya.I., \& Paskevych, G.A. (2019). Features of providing broiler chickens with exchange energy and protein as important indicators of productivity and quality of the obtained products. Scientific Messenger of Lviv National University of Veterinary Medicine and Biotechnologies. Series: Agricultural sciences, 21(91), 60-64. doi: 10.32718/nvlvet-a9110

The article deals with the possibility of using feed additives in the feeding of broiler chickens and the peculiarities of their effect on the poultry organism. Contemporary data on the biological role of nutrients and energy in the feeding of broiler chickens are presented. The characteristics of the main feeds for poultry and the ways of reducing their prime cost in the conditions of broiler farms are given. The basic principles of effective feeding of poultry with forages of different content of metabolic energy and crude protein are considered, taking into account their assimilation in the body. Provided compound feed recipes and practical tips. It is established that high growth rate of broiler chickens in the start and groove periods (5-39 days) is provided by high-protein compound feeds $-23 \%$ (12 weeks), 21\% (3-5 weeks) and exchange energy of $298 \mathrm{kcal}$ and $305 \mathrm{kcal}$, respectively. With further cultivation in the finish forage the protein content in the forage decreases and the level of metabolic energy increases (up to $309 \mathrm{kcal}$ ). However, for each cross applies its own technology of cultivation and different rates of nutrients in raw materials. It is clear that effective breeding of broiler chickens is not possible without the proper rationing and use of protein and feed energy. Of course, provided that the supply of biologically active substances also corresponds to the normalized amount. Thus, the quality of poultry products is directly dependent on the quality of feed and the efficiency of transformation of feed energy into products.

Key words: chickens-broilers, exchange energy, full-featured mixed fodder, productivity of poultry.

\section{Особливості забезпечення курчат-бройлерів обмінною енергісю та протеїном як важливі показники продуктивності та якості отриманої продукції}

\author{
Л.М. Фіялович, Я.І. Кирилів, Г.А. Паскевич
}

Львівський національний університет ветеринарної медицини та біотехнологій імені С.3. Гжицького, м. Львів, Україна

У статті розглянуто питання про можливість використання кормових добавок у годівлі курчат-бройлерів та особливості їхньої дї на організм птиці. Викладено сучасні дані про біологічну роль поживних речовин та енергії в годівлі курчат-бройлерів. Наведено характеристику основних кормів для птиці та шляхи зниження їхньої собівартості в умовах господарств бройлерного напряму. Описано основні принципи ефективної годівлі птиці комбікормами з різним вмістом обмінної енергії $і$ сирого протеїну з урахуванням їх засвоєння в організмі. Наведено рецепти комбікормів та вміщено практичні поради. Встановлено, шчо велика швидкість росту молодняку курчат-бройлерів в стартовий та гроуерний періоди (5-39 днів) забезпечується комбікормами з високим вмістом протеїну - 23\% (1-2 тиждень), 21\% (3-5 тиждень) і обмінної енергії 298 ккал та 305 ккал відповідно. При подальшому вирощуванні у фінішному комбікормі вміст протеїну в кормах знижується $і$ збільшується рівень обмінної енергії (до 309 ккал). Однак для кожного кросу застосовується своя технологія вирощування і різні норми пожсиних речовин у сировині. Зрозуміло, цчо 
ефективне вирощування курчат-бройлерів неможливе без правильного нормування та використання протеїну і енергї кормів. Звичайно, за умови, щз забезпечення біологічно активними речовинами також відповідає нормованій кількості. Таким чином, якість продукиії птахівництва перебуває у прямій залежності від якості кормів та ефективності трансформації енергії корму у продукиію.

Ключові слова: курчата-бройлери, обмінна енергія, повнораціонний комбікорм, продуктивність птиці.

Вступ

Науковий прогрес і практичні результати у птахівництві сягнули таких показників, що на перший план виходить питання правильності годівлі та нормування раціонів, оскільки при дотриманні всіх інших технологічних параметрів рівень продуктивності на 80\% залежить від цих показників (Otchenashko, 2012; Hunchak et al., 2016). Якість кормів має задовольняти потреби птиці в усіх поживних та біологічно активних речовинах, необхідних для іiі росту і розвитку та максимальній продуктивності (Sychov, 2015; Medvid et al., 2017; Sobolev et al., 2017).

У більшості сучасних господарств вміст та якість протеїну в кормах птиці не завжди відповідає науково доведеним потребам їхнього організму. Це призводить до порушення обміну речовин, значних перевитрат кормів, знижує продуктивність і підвищує собівартість продукції. Особливо зростає необхідність повноцінної годівлі в умовах вирощування птиці в закритих приміщеннях, де вищий ризик погіршення умов мікроклімату та внаслідок цього поширення інфекційних хвороб (Shurchkova et al., 2009; Kyryliv \& Hunchak, 2016; Fialovych et al., 2018).

На відміну від інших видів сільськогосподарської птиці, курчата-бройлери мають високу інтенсивність росту, тому із перших днів життя їх потрібно годувати комбікормами, збалансованими за всіма основними поживними та біологічно активними речовинами. Відповідно до нормативних програм годівля курчатбройлерів поділяється на три основні періоди: престартерний (1-3-й тижні); стартерний (4-5-й тижні); фінішний (6-й тиждень і старші) (Chornolata, 2016).

Аналіз останніх публікацій показує, що досліджень 3 вивчення особливостей годівлі курчат-бройлерів проведено багато. Зокрема, у роботах подано достатньо широку інформацію стосовно ролі поживних та біологічно активних речовин у живленні птиці та доцільність застосування кормових добавок у вигляді макро- та мікроелементів, вітамінів, антиоксидантів та інших біологічно активних речовин природного походження у птахівництві (Kyryliv \& Ratych, 2000; Prudyus et al., 2016).

Метою даних досліджень було вивчення особливостей годівлі курчат-бройлерів в умовах господарств західного регіону з метою узагальнення інформації щодо оцінки їхньої продуктивності.

\section{Результати та їх обговорення}

Основним компонентом комбікормів для птиці є злакові, такі як кукурудза і пшениця, дещо менше використовується ячмінь, ще менше - жито та овес (Bratyshko \& Prytulenko, 2012).

В Україні широко розповсюджено використання раціонів на основі кукурудзи, соняшникової, соєвої макухи і шроту. У Свропі, залежно від країни, більше використовують сою, в Україні - менше. Варто зазначити, що в Україні раціони дешевші завдяки нижчій собівартості кормових інгредієнтів та власній кормовій базі.

Для вирощування курчат-бройлерів у господарствах використовуються програми годівлі та рекомендації, розроблені й запропоновані фірмами, що пропонують різні варіанти годівлі, пристосовані до сировини наявної в Україні, її якості та ціни. А також $є$ можливість виготовлення однорідного комбікорму на власній середній та великій фермах із застосуванням власного обладнання, щоб повністю забезпечити себе кормами і мати змогу контролювати їх якість.

Типові стартерні раціони для бройлерів містять 21-24\% протеїну, а для курей-несучок - 15-17\%. Зерно і відходи його переробки забезпечують приблизно половину потреби в протеїні в більшості раціонів для курей (Yatsenko, 2015).

Високопротеїновими концентратами рослинного або тваринного походження забезпечується додатковий протеїн. Білки зерна злакових мають нижчу біологічну цінність, ніж білки бобових, макухи, шротів і кормів тваринного походження. За браку як протеїну, так і окремих амінокислот у раціоні птиці знижується швидкість іiі росту і погіршуються показники якості м'яса (Shurchkova et al., 2009; Yatsenko, 2015).

Для прикладу наводимо орієнтовний рецепт повнораціонного комбікорму для годівлі курчатбройлерів різного віку (табл. 1).

Раціони були проаналізовані за вмістом енергії і протеїну. У кожному комбікормі відзначені невеликі розбіжності між проаналізованими концентраціями енергетичних і протеїнових джерел. Склад і поживність комбікорму змінюється залежно від віку курчатбройлерів.

Як видно з таблиці, велика швидкість росту молодняку курчат-бройлерів в стартовий та гроуерний періоди (5-39 днів) забезпечується комбікормами 3 високим вмістом протеїну - 23\% (1-2 тиждень), 21\% (3-5 тиждень) і обмінної енергії 298 ккал та 305 ккал відповідно.

Поживність сирого протеїну раціонів була знижена на $2 \%$ за рахунок зменшення рівня додавання дорогих соєвої макухи і шроту і заміна їх на дешевшу пшеницю.

При подальшому вирощуванні у фінішному комбікормі вміст протеїну в кормах знижується і збільшується рівень обмінної енергії (до 309 ккал).

За даними В.I. Фісініна, з метою забезпечення інтенсивного росту курчат-бройлерів добове споживання обмінної енергії з добового до 4-тижневого віку становить 3153, а в 4-тижневому віці - 3190 ккал/кг корму (Fisinin, 2002).

Для кожного кросу застосовується своя технологія вирощування і різні норми поживних речовин у сиро- 
вині. Крос Кобб-500 не дуже вимогливий до кількості протеїну у раціоні. Птиці достатньо 20 \% протеїну на старті і 17,5-17\% на фініші. А для Росс-308 потрібно мінімум 20-23\% протеїну на старті та не менш ніж 20\% на фініші (Dychakovska, 2011).

Доцільно розглядати високу продуктивність птиці як першочерговий показник нормованої забезпеченості іiі енергією та протеїном. Звичайно, за умови, що забезпечення вітамінами та макро- й мікроелементами також відповідає нормованій кількості (Chornolata \& Zdor, 2015).

Зменшити витрати концентрованих кормів 3 одночасним підвищенням енергетичної та протеїнової поживності раціонів можна за рахунок заміни частини зернової основи продуктами переробки олієекстракційного виробництва - макухою або шротом (Slavianska et al., 2012).

\section{Таблиця 1}

Структура комбікормів для відгодівлі курчат-бройлерів різного віку, \%

\begin{tabular}{|c|c|c|c|}
\hline \multirow{3}{*}{ Корм } & \multicolumn{3}{|c|}{ Період вирощування, днів } \\
\hline & $5-13$ & $14-39$ & $40-47$ \\
\hline & Стартер & Гроуер & Фінішер \\
\hline Кукурудза & 18 & 20 & 20 \\
\hline Пшениця & 33,4 & 36,5 & 42,3 \\
\hline Макуха соєва & 33 & 22,3 & 11,7 \\
\hline Шрот соняшниковий & 4 & 6 & 8 \\
\hline М'ясо-кісткове борошно & 5 & 7,5 & 10 \\
\hline Олія рослинна & 1,6 & 2,7 & 3 \\
\hline Крейда, вапняк & 1,8 & 1,8 & 1,8 \\
\hline Монокальційфосфат & 1,3 & 1,3 & 1,3 \\
\hline Сіль кухонна & 0,4 & 0,4 & 0,4 \\
\hline Вітамінно-мінеральний премікс & 1,5 & 1,5 & 1,5 \\
\hline Разом: & 100 & 100 & 100 \\
\hline \multicolumn{4}{|c|}{ У 100 г комбікорму міститься, \%: } \\
\hline Обмінної енергії, ккал & 298 & 305 & 309 \\
\hline Сирого протеїну & 23 & 21 & 19 \\
\hline Сирого жиру & 4,30 & 5,60 & 6,41 \\
\hline Сирої клітковини & 3,81 & 4,43 & 4,81 \\
\hline Кальцію & 0,91 & 0,90 & 0,85 \\
\hline Фосфору & 0,64 & 0,71 & 0,72 \\
\hline Натрію & 0,16 & 0,15 & 0,15 \\
\hline Лізину & 1,30 & 1,20 & 1,06 \\
\hline Метіоніну + цистину & 0,97 & 0,85 & 0,81 \\
\hline
\end{tabular}

Отримані результати свідчать про те, що значну частину раціонів становить соєва макуха - близько $33 \%$. Широке використання соєвої макухи та шроту в комбікормах для годівлі курчат-бройлерів (до 33\%) виправдане. Соєві макуха i шрот для молодняку i дорослої птиці є джерелом біологічно повноцінного протеїну, оскільки містять його $41-43 \%$ і більше. Цими компонентами в раціоні птиці можна замінювати продукти тваринного походження (Melnyk, 2007). Соєва макуха має перевагу в якості енергетичних джерел сировини 3 високим вмістом лінолевої кислоти, дефіцит якої гальмує ріст молодняку (Ostapkevych, 2005).

Однак соєвий шрот не завжди є доступним джерелом білка через високу вартість. Часто як альтернативу використовують інші рослинні компоненти з високим вмістом білка, зокрема бобові зернові культури. Комбікормові заводи в такий спосіб намагаються заощадити на вартості раціону. Однак включення нетрадиційних джерел білка має свої недоліки (Slavianska, 2016).

У наших умовах дешевший протеїн забезпечить таке джерело як соняшниковий шрот. Використання соняшникового шроту $є$ вигіднішим порівняно 3 iншими кормами. Однак високий вміст клітковини (шрот - 9,8\%, макуха - 13,3\%) обмежує введення їх в раціони курчат-бройлерів і вимагає застосування екзогенних ферментних препаратів целюлозолітичної діï.

Соняшниковий шрот застосовується в раціонах бройлерів у високих дозах, на рівні 8-15\%. Це робиться 3 метою зниження застосування дорожчих соєвих продуктів і більшої економії. Однак використання альтернативних джерел білка пов'язане 3 певними труднощами 3 доступністю і засвоєнням поживних речовин. Такі джерела містять меншу кількість доступного білка, порівняно із соєвим шротом. Крім того, в них міститься більше антипоживних факторів, що призводять до зниження засвоєння птицею протеїну та енергії корму (Svann, 2015).

У процесі відгодівлі використовують м'ясокісткове борошно із високим рівнем протеїну та повноцінним складом амінокислот, що найбільш близькі до потреб моногастричних тварин. М'ясо-кісткове борошно $є$ джерелом повноцінного протеїну, вітамінів, мінеральних речовин із високою доступністю й засвоюваністю. Загалом аналіз джерел літератури свідчить, що у комбікорми для дорослої птиці рекомендується додавати - до 10\%. Проте варто враховувати високу бактеріальну забрудненість м'ясокісткового борошна (Ostapkevych, 2005). 
На поліпшення економічних показників, особливо у птахівництві, впливає і застосування у раціонах більшої частки протеїну рослинного походження, що, як відомо, здешевлює виготовлення комбікормів і, як наслідок, яєць та м'яса бройлерів (Chudak et al., 2009). Проте підвищення рівня застосування вимагає додавання до раціону екзогенних ферментних препаратів різнобічної дії (Barnard, 2015).

Головним чинником, що лімітує м'ясну та яєчну продуктивність птиці, безумовно, є швидкість синтезу білків в організмі. Інтенсивність цього процесу прямо залежить від надходження повноцінного протеїну 3 кормом (Yatsenko, 2015).

Протеїн відіграє першочергову роль у побудові тіла та життєдіяльності тваринного організму. Птиця ефективно засвоює протеїн корму і перетворює його в білки своєї продукції (Sychov, 2015).

Для забезпечення повноцінної годівлі птиці корм має містити не лише достатню кількість протеїну, важливим $є$ його якість, зумовлена наявністю незамінних амінокислот. За їхнього дефіциту птиця знижує продуктивність (Ponomarenko \& Krasnoshchok, 2007).

Для покращення дефіциту в корми додають синтетичні препарати амінокислот, що дає змогу значно знизити рівень використання тваринного протеїну у комбікормі, розширити застосування протеїнів рослинного походження, що веде до здешевлення кормів для годівлі курчат-бройлерів (Ostapkevych, 2005).

В сучасному птахівництві годівля дефіцитніша за вмістом обмінної енергії, ніж за протеїном чи іншими поживними речовинами. Нестача енергії в кормах поширена причина зниження продуктивності птиці (Sychov, 2019).

Птиця задовольняє свою потребу в енергії переважно за рахунок вуглеводів і жирів. Найефективніше вона використовує декстрини, цукри й крохмаль (Ibatullin et al., 2014).

Вуглеводи й жири - основний енергетичний матеріал, що надходить до організму птиці з кормом, де перетворюється на біологічну енергію. Організм може нагромаджувати вуглеводи у вигляді жирових відкладень. За необхідності (при голодуванні, під час хвороби, при виснаженні) організм їх використовує для поповнення енергії (Borodai et al., 2007).

Рівень обмінної енергії в раціоні є одним із найважливіших факторів, що визначає споживання корму, ефективність використання поживних речовин в організмі птиці та є одним із основних чинників впливу на її продуктивність (Otchenashko, 2012).

Вміст енергії в раціоні - один з найбільш важливих показників оцінки його якості. Навіть при наявності в раціоні всіх інших поживних речовин його ефективність залежить від вмісту достатньої кількості енергії (Ostapkevych, 2005).

Відомо, що комбікорми для птиці на 60-70\% складаються із зернових кормів, які містять 65-80\% вуглеводів, що є джерелом енергії (Osipenko, 2015).

За даними науково-дослідної лабораторії компанії "Danisco", близько 66\% обмінної енергії кукурудзи міститься у формі крохмалю і приблизно 8\% - у формі олії. Тобто за вмісту у стартовому комбікормі для курчат-бройлерів 65\% кукурудзи 70\% потреби в обмінній енергії раціону покриваються за іiі рахунок (або 45\% - за рахунок кукурудзяного крохмалю) (Verner \& Sytko, 2012).

Раціони для годівлі курчат-бройлерів - високоенергетичні і містять до 6\% жиру. Тому забезпечити високий рівень енергії в раціоні неможливо тільки за рахунок вуглеводів зернових кормів. Включення менших кількостей зерна кукурудзи знижує енергетичну поживність комбікорму, тому з метою підтримання енергії раціону в комбікорми додають кормові жири як рослинного, так і тваринного походження.

Постійне вирішення білкової проблеми в нашій країні зовсім не відтіснило на задній план проблему енергії, оскільки зерно кукурудзи як головне ії джерело для птиці було і надалі залишається доволі дорогим (Yatsenko, 2016).

Підвищення рівня енергії в раціонах курчатбройлерів досягається додаванням в корми жирів рослинного походження - соєву, соняшникову та інші рослинні олії. Олія - дуже важлива складова раціону, особливо у другий період вирощування (Dychakovska, 2011). Рівень додавання жиру в комбікорми для птиці коливається в межах 1,6-3\% (табл. 1).

При застосуванні кормового жиру у бройлерів поліпшується ріст і якість їх м'яса. Вони також покращують смакові якості й виступають зв'язувальним компонентом комбікормів.

Ліпіди кормів, як і жирові добавки, є важливим i легкодоступним джерелом енергії у раціонах птиці. Ефективність застосування жирових добавок передусім залежить від походження жиру. Доведено, що рівень засвоєння кормових жирів тваринного походження нижчий (60-70\%), ніж рослинних (80-90\%), а суміш тваринних і рослинних жирів засвоюється на 80-85\% (Sychov, 2014).

Ефективність використання енергії раціону залежить від віку птиці та іiі фізіологічного стану. Якщо обмінної енергії птиці не вистачає, сирий протеїн використовується організмом на енергетичні цілі, що супроводжується збільшенням споживання корму i затрат на одиницю продукції (Khvostyk, 2015).

Енергетично насичені корми використовуються в організмі бройлерів більш ефективно за фактично однакового їх споживання i зменшення витрат на одиницю приросту. Отже, для курчат енергетична насиченість раціону - важливий елемент для підвищення ефективності використання протеїну корму i перетворення його на білок м'язів тушки. Додаткове додавання в раціон жиру дозволяє більш ефективно використовувати протеїн корму і забезпечує інтенсивний приріст живої ваги курчат (Menzhyk, 2016).

Інколи ситуація із кормами на ринку України є досить важкою, в той період коли є відчутний брак зерна і висока ціна на такі компоненти, як соєвий шрот чи олія є досить важко досягнути добрих економічних результатів.

\section{Висновки}

Отже, високий рівень продуктивності при вирощуванні курчат-бройлерів може бути досягнутий 
лише при використанні збалансованих за всіма показниками раціонів, що складаються 3 доброякісних та доступних за ціною кормових компонентів.

Перспективи подальших досліджень. Необхідні подальші дослідження 3 метою визначення впливу нетрадиційних кормових добавок на якість продукції птахівництва.

\section{References}

Barnard, L. (2015). Pozytyvna diia kombinatsii fermentiv. Nashe ptakhivnytstvo, 3(39), 64-66 (in Ukrainian).

Borodai, V.P., Melnyk, V.V., \& Bazyvoliak, S.M. (2007). Hodivlia perepeliv. Suchasne ptakhivnytstvo, 8-9 (57-58), 14-17 (in Ukrainian).

Bratyshko, N., \& Prytulenko, O. (2012). Trytykale v hodivnytsi. Nashe ptakhivnytstvo, 1, 42-43 (in Ukrainian).

Chornolata, L. (2016). Mikroelementy dlia kurchat-broileriv. Nashe ptakhivnytstvo, 10, 50-52 (in Ukrainian).

Chornolata, L., \& Zdor, L. (2015). Rozrakhunok vitaminiv. Nashe ptakhivnytstvo, 5(41), 47-49 (in Ukrainian).

Chudak, R., Ohorodnichuk, H., Shevchuk, T., Adler, O., \& Prokopchuk, I. (2009). Nut u hodivli kurchat-broileriv. Tvarynnytstvo Ukrainy, 2, 37-39 (in Ukrainian).

Dychakovska, V. (2011). Nyzki pryrosty - nedozvolena rozkish! Nashe ptakhivnytstvo, 4, 24-27 (in Ukrainian).

Dychakovska, V. (2011). Rentabelnist ochyma zootekhnika. Nashe ptakhivnytstvo, 5, 36-37 (in Ukrainian).

Fialovych, L.M., Kyryliv, Ia.I., \& Paskevych, H.A. (2018). Production of geese at using unconventional additions in mixed fodder. Scientific Messenger of Lviv National University of Veterinary Medicine and Biotechnologies, 20(84), 127-130. doi: 10.15421/nvlvet8423.

Fisinin, V. (2002). Polnotsennoe pitanie ptytsy kachestvo i rentabelnost produktsii. Kombikorma, 1, 42-45 (in Russian).

Hunchak, A.V., Ratych, I.B., Gutyj, B.V., \& Paskevych, H.A. (2016). Metabolic effects of iodine in poultry for its deficiency or excess in the diet. Scientific Messenger LNUVMBT named after S.Z. Gzhytskyj, 18, 2(67), 70-76. doi: 10.15421/nvlvet6716.

Ibatullin, I.I., Kryvenok, M.Ia., \& Ilchuk, I.I. (2014). Teoretychne ta eksperymentalne obhruntuvannia zminy potreb kurei batkivskoho stada $u$ treonini $i$ metionini zalezhno vid viku ta produktyvnosti. Suchasne ptakhivnytstvo, 2(135), 4-7 (in Ukrainian).

Khvostyk, V. (2015). Kormovi potreby perepeliv. Nashe ptakhivnytstvo, 3(39), 60-63 (in Ukrainian).

Kyryliv, B., \& Hunchak, A. (2016). The influence of alimentary factors on productivity hens. Scientific Messenger of LNU of Veterinary Medicine and Biotechnologies, 18(2(67), 287-291. doi: $10.15421 /$ nvlvet6762.

Kyryliv, Ya.I., \& Ratych, I.B. (2000). Otsinka yakosti kombikormiv dlia ptytsi i produktsii ptakhivnytstva. Navchalnyi posibnyk (in Ukrainian).
Medvid, S.M., Hunchak, A.V., Gutyj, B.V., \& Ratych, I.B. (2017). Prospects of rational security chicken-broilers with mineral substances. Scientific Messenger LNUVMB, 19(79), 127-134. doi: 10.15421/nvlvet7925.

Melnyk, V.V. (2007). Kormy dlia ptytsi. Suchasne ptakhivnytstvo, 5-6(54-55), 14-20 (in Ukrainian).

Menzhyk, T. (2016). Hotuiemo kurei do speky. Nashe ptakhivnytstvo, 3(45), 47-49 (in Ukrainian).

Osipenko, O. (2015). Maiesh fermenty - ekonomysh koshty. Nashe ptakhivnytstvo, 5(41), 58-60 (in Ukrainian).

Ostapkevych, V. (2005). Osoblyvosti hodivli indykiv vazhkykh krosiv. Efektyvne ptakhivnytstvo, 1, 23-26 (in Ukrainian).

Otchenashko, V. (2012). Upravlinnia rostom. Nashe ptakhivnytstvo, 2, 37-39 (in Ukrainian).

Ponomarenko, N.P., Krasnoshchok, V.H. (2007). Khvoroby perepeliv ta yikh profilaktyka. Suchasne ptakhivnytstvo, 10-11(59-60), 34-40 (in Ukrainian).

Prudyus, T.Ya., Kyryliv, Ya.I., \& Barylo, B.S. (2016). Vplyv biolohichno aktyvnoi kormovoi dobavky aktyvio na deiaki pokaznyky lipidnoho obminu ta antyoksydantnyi stan kurchat-broileriv. Naukovyi visnyk LNUVMBT im. S.Z. Gzhytskoho. 18, 1(65), 111-116 https://nvlvet.com.ua/index.php/agriculture/ article/view/3511/3479 (in Ukrainian).

Shurchkova, Yu., Hanzenko, V., \& Radchenko, N. (2009). Proteinovyi korm dlia ptytsi. Tvarynnytstvo Ukrainy, 5, 35-36 (in Ukrainian).

Slavianska, V. (2016). Pravylnyi vybir kombikormu. Nashe ptakhivnytstvo, 2(44), 72-73 (in Ukrainian).

Slavianska, V., Lenkova, T., \& Yehorova, T. (2012). Chy buty $\mathrm{v}$ ratsionakh ripaku? Nashe ptakhivnytstvo, 1, 54-57 (in Ukrainian).

Sobolev, A.I., Gutyj, B.V., Petryshak, O.I., Golodjuk, I.P., Petryshak, R.A., \& Naumyuk, O.S. (2017). Morphological and biochemical blood indicators of ducklings, which are raised for the purpose of meat with the different level of selenium in feeding-stuffs. Scientific Messenger LNUVMBT named after S.Z. Gzhytskyj, 19(74), 57-62. doi: 10.15421/nvlvet7413.

Svann, D. (2015). Dostupna alternatyva. Nashe ptakhivnytstvo, 4(40), 55-58 (in Ukrainian).

Sychov, M. (2014). Enerhetychnyi holod. Nashe ptakhivnytstvo, 1(31), 45-47 (in Russian).

Sychov, M. (2015). Dzherela metioninu. Nashe ptakhivnytstvo, 4(40), 60-63 (in Russian).

Sychov, M. (2015). Vplyv na rist kurchat-broileriv. Nashe ptakhivnytstvo, 5(41), 62-64 (in Russian).

Sychov, M. (2019). Zbalansovane spivvidnoshennia. Nashe ptakhivnytstvo, 1(61), 66-69 (in Russian).

Verner, O., \& Sytko, O. (2012). Komponentam kormu peretravnist! Nashe ptakhivnytstvo, 1, 48-49 (in Ukrainian).

Yatsenko, O. (2015). Protein dlia kurchat-broileriv. Nashe ptakhivnytstvo, 6(42), 62-65 (in Ukrainian).

Yatsenko, O. (2015). Yakist kurchat-broileriv i treonin. Nashe ptakhivnytstvo, 5(41), 74-75 (in Ukrainian).

Yatsenko, O. (2016). Netradytsiine rishennia. Nashe ptakhivnytstvo, 2(44), 47-49 (in Ukrainian). 